The following are notes of three cases showing the value of the treatment :

CASE I.-M. B., aged 18. History of haemoptysis. No family history. Impaired note and râles at the right base. V. Pirquet' test definite. After fourteen weeks' treatment the râles had entirely disappeared. Increase of $15.1 \mathrm{~b}$. in weight. Has enlisted as a soldier.

CASE II.-F. B., aged 18. History of loss of weight and cough. Brother had pulmonary tuberculosis. Impaired note and weak breathing at the right apex.. Apical percussion change above the right clavicle. Von Pirquet's test positive. Gained $7 \frac{1}{2} \mathrm{lb}$. in nine weeks. He is now working as a commercial traveller.

CASE III.-A. R., aged 40. Flattening, diminished movement and impaired note over the right side of the chest. Tubercle andill in the note over the right side of the chest. Tubercle bacilli in the sputum. Rales over the right side of the chest. There was no improvement for a few weeks, and he was steadily losing weight until carbolic acid was given; he then immediately began to improve and gain weight. Before he left the sana torium he was looking after the greenhouses and acting as postman. This is one of the advanced cases which received
benefit from the treatment.

In conclusion, I would like to thank Dr. Woodcock and Dr. Watson, honorary physicians to the Leeds Sanatorium for Consumptives, for allowing me to publish these cases.

\section{A REPORT ON}

\section{FIFTY CASES OF TRACHOMA TREATED WITH CARBON DIOXIDE SNOW.}

By G. MONTAGU HARSTON, M.D.LoND., OPHTHALMIC SURGEON, TUNG WA HOSPITAL, HONG KONG.

From time to time various skin affections, warts, rodent ulcers, etc., new growths, such as naevi and other cutaneous affections, have been reported in the Journal as cured by means of the application of carbon dioxide snow. I now report a series of 50 cases of trachoma which have been treated by me at the Tung Wa Hospital, Hong Kong, with the same remedy. The cases are all Chinese. In addition I have treated a number of cases in private with equally successful results. My attention was first called to this method by Mr. Bishop Harman, who exhibited a case he had treated, at the last annual meeting of the British Medical Association (July, 1910). The case he then showed was completely cured, the conjunctiva exhibiting a smooth cicatricial appearance with no trace of the disease beyond the scarring inevitable in the process of cure when the disease has persisted for any length of time.

Method of Procedure.

The snow is collected from a 28-1b. cylinder of the liquefied gas by means of a Prana cage. The cage is then detached from the cylinder and the snow is rammed down tightly into the cylindrical mould attached to the cage; I then hammer down the snow in the mould to compress it as much as possible, and to facilitate subsequent shaping of the resulting pencil. The pencil is now extruded with the stick provided for the purpose, and subsequently shaped with a blunt knife into the form of a sharpened pencil, the sloping point being made as long as possible, but thick enough to avoid fracture when applied to the everted conjunctiva. This is an important point, as considerable pressure has to be applied to secure the maximum of efficiency. The surgeon stands behind the patient and everts the lids in the ordinary way; holding the lids everted with the fingers of the left hand, he takes up the pencil of snow with the right hand and applies it to the conjunctiva, taking care to avoid contact with the cornea, and at the same time directing the patient to look down as much as possible, so that the snow may be applied to the transitional fold of conjunctiva in the fornices. After treating the fold of transition the snow is applied to the tarsal conjunctiva, an interval being allowed to elapse so that the effect may pass off from the fornices before applying any pressure on the tarsal conjunctiva. The reason for this will be easily appreciated by the surgeon should the patient inadvertently raise the eyeball; the cornea is then apt to come into contact with the excess of snow deposited. Pain immediately ensues, and blepharospasm naturally follows, markedly exaggerating the discomfort of the patient. In the same way, after applying the snow to the tarsal conjunctiva, an interval is allowed to elapse before replacing the everted lid.
At the first application the snow is applied to each part for fifteen seconds ; later, when the patient is accustomed to the treatment, for as long as twenty, twenty-five, and thirty seconds. The pain caused passes off at the end of two minutes, and is infinitesimal compared to the pain caused by bluestone, silver nitrate, and such like caustics. The disease is considerably shortened in its course, and the resulting scarring is considerably less than when other caustics have been used. In the following series of cases the applications were made once weekly. Provided Bowman's membrane is intact, pannus and corneal ulceration clear up rapidly in the majority. The worst cases to treat are those of acute trachoma, with much oedema of the lids and conjunctivae and much purulent secretion. The cases which respond most rapidly are those which have already become chronic, with slight discharge, wad with slight scarring-that is to say, those cases in which Nature has already attempted a cure. Of the papillary and granular types of the disease, the latter is, in my experience, the more readily amenable to the treatment with snow.

Amongst the cases treated was one of typical xerosis, which improved considerably, the dryness of the cornea having now completely disappeared. Hitherto this condition has been quite intractable as far as treatment is concerned, and, while it may be considered somewhat rash to draw conclusions from one case, perhaps other observers may be able to report further on this hopeless sequel to trachoma.

I append a list in brief of the cases treated.

Table of Cases.

\begin{tabular}{|c|c|c|c|}
\hline $\begin{array}{c}\text { No. } \\
\text { of } \\
\text { Case. }\end{array}$ & Description. & $\begin{array}{c}\text { No. of } \\
\text { Applica- } \\
\text { tions. }\end{array}$ & Result. \\
\hline 1 & $\begin{array}{l}\text { Acute papillary, much congestion } \\
\text { of conjunctiva, cornea clear }\end{array}$ & 15 & Cure. \\
\hline 2 & $\begin{array}{l}\text { Chronic, slight discharge, scarring } \\
\text { commencing }\end{array}$ & 5 & Cure. \\
\hline 3 & Incipient, follicles in fornices only & 5 & Cure. \\
\hline 4 & Acute papillary (vide Case 1) & 15 & Cure. \\
\hline 5 & Incipient (vide Case 3) & 7 & Cure. \\
\hline 6 & $\begin{array}{l}\text { Chronic, pannus, and corneal } \\
\text { ulceration }\end{array}$ & 16 & Cure. \\
\hline 7 & Ditto & 12 & Cure. \\
\hline 8 & Incipient (vide Case 3) & 8 & Cure. \\
\hline 9 & Chronic, pannus & 8 & Cure. \\
\hline 10 & Chronic, corneal ulceration & 8 & Cure. \\
\hline 11 & Chronic, granular, corneal ulcera- & 9 & Cure. \\
\hline 12 & Chronic, papillary, corneal ulcera- & 15 & Cure. \\
\hline 13 & $\begin{array}{l}\text { Chronic, granular, scarring, nebu- } \\
\text { lae on cornea }\end{array}$ & 11 & Cure. \\
\hline 14 & Chronic & 4 & Did not continue. \\
\hline 15 & Chronic, granular, pannus & 10 & Cure. \\
\hline 16 & Acute papillary & 17 & Cure. \\
\hline 17 & $\begin{array}{l}\text { Chronic, encysted follicles, expres- } \\
\text { sion of upper lid }\end{array}$ & 7 & Cure. \\
\hline 18 & Acute velvety & 9 & Cure. \\
\hline 19 & Chronic, granular, nebulae & 8 & Cure. \\
\hline 20 & Chronic, papillary & 12 & Cure. \\
\hline 21 & Chronic, scarring advanced & 4 & Cure. \\
\hline 22 & Ditto & 5 & Cure. \\
\hline 23 & $\begin{array}{l}\text { Follicles confined to fornices, some } \\
\text { ulceration of right cornea }\end{array}$ & 11 & Cure. \\
\hline 24 & $\begin{array}{l}\text { Chronic, granular, complete pan- } \\
\text { nus in left eye causing blindness; } \\
\text { partial pannus in right eye }\end{array}$ & 15 & $\begin{array}{l}\text { Vision of right } \\
\text { eye saved: lids } \\
\text { cured. }\end{array}$ \\
\hline 25 & Chronic granular & 10 & Cure. \\
\hline 26 & Incipient & 6 & Cure. \\
\hline 27 & Chronic, granular, pannus & 12 & Cure. \\
\hline 28 & Chronic, searring advanced & 4 & Cure. \\
\hline 29 & Ditto & & Cure. \\
\hline
\end{tabular}


Table of Cases (continued).

\begin{tabular}{|c|c|c|c|}
\hline $\begin{array}{c}\text { No. } \\
\text { of } \\
\text { Case. }\end{array}$ & Description. & $\begin{array}{l}\text { No. of } \\
\text { Applica- } \\
\text { tions. }\end{array}$ & Result. \\
\hline 30 & Chronic & 6 & Cure. \\
\hline 31 & Chronic, granular, pannus left eye & 9 & Cure. \\
\hline 32 & Vide 28 & 7 & Cure. \\
\hline 33 & Ditto & 6 & Cure. \\
\hline 34 & Chronic, papillary & 2 & Did not return. \\
\hline 35 & Chronic, scarring advanced & 6 & Cure. \\
\hline 36 & Ditto & 7 & Cure. \\
\hline 37 & Entropion vision P.L. & 1 & Did not return. \\
\hline 38 & Acute papillary & 18 & Cure. \\
\hline 39 & Chronic, papillary & 14 & Cure. \\
\hline 40 & Chronic, scarring advanced & 9 & Cure. \\
\hline 41 & Acute papillary & 10 & $\begin{array}{l}\text { Still under treat- } \\
\text { ment. }\end{array}$ \\
\hline 42 & Old cicatrices in lids, pannus & 7 & Cure. \\
\hline 43 & Vide 40 & 8 & $\begin{array}{l}\text { Still under treat- } \\
\text { ment. }\end{array}$ \\
\hline 44 & Chronic granular & 9 & Cure. \\
\hline 45 & Ditto & 13 & Cure. \\
\hline 46 & Old case, expression done & 5 & Cure. \\
\hline 47 & Acute papillary & 8 & Under treatment. \\
\hline 48 & $\begin{array}{l}\text { Acute granular, corneal ulcera- } \\
\text { tion in right eye; no ulceration, } \\
\text { slight pannus left eye }\end{array}$ & 7 & $\begin{array}{l}\text { Ulceration healed; } \\
\text { under treatment. }\end{array}$ \\
\hline 49 & Chronic xerosis & 8 & $\begin{array}{c}\text { Xerosis cured ; } \\
\text { under treatment. }\end{array}$ \\
\hline 50 & Acute granular & 5 & $\begin{array}{l}\text { Improved under } \\
\text { treatment. }\end{array}$ \\
\hline
\end{tabular}

Result refers to the lid condition only where not otherwise stated. The pannus improved in all cases, but persisted in some. In private disappearance provided Bowman's membrane is intact.

\section{ADMINISTRATION OF SERUM BY THE MOUTH.}

By G. I. CUMBERLEGE, M.D.Durh., CARDIFF.

During the last few months there has been a good deal of controversy in the pages of the Journal with regard to the relative merits of diphtheritic antitoxin given hypodermically and by the mouth.

As one who has almost entirely used the later method, I feel it may be of benefit to state why to my mind it is a better method than by hypodermic injection. My own experience, unfortunately, only dates back four years; but I first learnt of this method when assistant to Dr. Hunton of Sedgefield, co. Durham-a method which he had used entirely for a considerable number of years in his own private practice and as medical officer in charge of a fairly large fever hospital to which patients were sent from a very large and populous mining district.

During the four years, more especially the year spent at Sedgefield, I have come across a considerable number of cases, and up to the present have been fortunate enough to only have one death, a fact which in itself surely speaks well for mouth treatment. Moreover, the one and only death was in the case of a child aged 7 years, who had already been ill five days, death occurring from a sudden syncopal attack half an hour after she had been admitted to the hospital.

To sum up the points in favour. First of all with regard to efficacy, I have always found results of its action within a few hours after being given, and even if hypodermic injection is more speedy, so long as the infection is not of many days' duration, an hour or so difference can surely matter little, and that results are quick and good is borne out by the two cases mentioned.
As to dosage, I believe it is customary in hypodermic injections to give many thousand units on the supposition that, owing to possible untoward results arising from the serum, it is better to get it all in at once.

Given by the mouth a far smaller dose is required, and I have never given - more than 4,000 units at a time; a dose of 2,000 units, followed up, if necessary, by a further dose, is the usual amount given.

Again, the chief cause of death is due to heart failure, owing to the effects on the muscle of the diphtheritic toxins. As diphtheria is chiefly a disease of childhood, the pain caused by and fear of the needle usually means a struggle with the patient, and consequently there is an always present risk of too much strain upon the heart. Given by the mouth this risk is entirely obviated, and if given in a little water it seems to make a quite palatable mixture which young children take without any difficulty.

By giving it in this way, too, it is possible to give continued dosage by making into a mixture and ordering it to be given every two or four hours as the case may be. Shortly after giving the serum there is in most cases a diaphoresis and fall in temperature and pulse-rate, and also the patient falls into a deep sleep. Both these results I have noticed when giving serum other than diphtheritic, and I have often wondered whether the serum itself could have any narcotic effect, or whether it was due to the fall in temperature and rapid neutralization of toxins.

With regard to the action on serum by the gastric juices I am not able to speak, not having had any opportunity of making chemical tests; but, whatever the action may be, results seem to point towards no harm being done to the serum, whether given after food or on an empty stomach.

Another point in favour is that no patient treated by me by mouth has shown signs of serum sickness, whereas either a rash or joint pains, or both, has nearly always occurred after the few cases injected. It has been stated that serum causes paralyses, and if that is so, mouth treatment in that respect is no better and no worse than by injection, for it does occur, but practically only after bad cases, which probably, but for serum, would have died. The two following cases will help to bear out the efficacy of mouth treatment:

CASE I.

A boy, aged 15, when first seen had already been ill four days: On examination the throat contained one large sloughing mass extending over the whole of the pharynx, covering both tonsils and passing forwards on to the buccal mucous membrane. The nd passing for nose was completely blocked, so that breathing was extremely difficult, whilst pieces of membrane could be seen protruding rom the nostrils. There were the accompanying severe signs of toxaemia, with enormous swelling and matting together of glands in the neck. Within eight hours of the first dose (4,000 units) there were already signs of improvement in his general condition, breathing was much easier, and there were even fears of haemorrhage owing to the large shreds of membrane being coughed up; 4,000 units more were given, and next morning nasal breathing was quite easy, and the boy, to his intense relief, was able to blow his nose.

Altogether 30,000 units were given by small doses, morning and evening, for six days, by which time all traces of membrane had disappeared, and the boy seemed quite well.

I have since thought the boy would have done equally well on a smaller quantity of serum. In this case it was given night and morning till the boy was well. In other cases I have given an initial dose, and, providing toxic signs were clearing away, even though the temperature had not come down to normal within twelve hours, waiting another twelve hours often had the desired effect without giving more serum.

CASE II.

A girl, aged 13 years. Seen on second day of illness. Temperature, $102.2^{\circ}$; pulse, 102. Complained only of feeling ill. The girlshowed toxic signs, had enlarged glands in the neck and large masses of membrane on both tonsils. Serum, 2,000 units, was masses of membrane on both tonsils. Serum, 2,000 units, was
given, and by morning the temperature had fallen to $100.8^{\circ}$, given, and by morning the temperature had fallen to $100.8^{\circ}$, pulse 96. By the evening the temperature had only fallen to
$100.4^{\circ}$, pulse 92 , and as the girl still felt and looked ill, another $100.4^{\circ}$, pulse 92 , and as the girl still felt and looked ill, another
2,000 units was given. Next morning the temperature was $99.2^{\circ}$, 2,000 units was given. Next morning the temperature was $99.2^{\circ}$,
pulse 84 , and by evening the temperature was normal. The pulse 84 , and by evening the temperature was normal. The
child felt perfectly well and the membrane was rapidly clearing away.

From this onwards the temperature kept slightly subnormal and convalescence was non-interrupted. 